\title{
吉野川河口干潟のカ二類を対象とした生息環境評価モデルの検討 \\ Study on the Habitat Assessment Model for Sand Crab Family on the Tidal Flat in the Yoshino River
}

\author{
藤田真人 ${ }^{1} \cdot$ 中野 晋 $^{2} \cdot$ 山添美波 $^{3} \cdot$ 仙波真一 $^{4}$ \\ Masato FUJITA, Susumu NAKANO, Minami YAMAZOE and Shinichi SENBA
}

\begin{abstract}
The habitat assessment models for 4 species in sand crab family, those are Uca arcuata, Uca lactea, Mcrophthalmus japanicus and Ilyoplax pusilla, were developed by using the HSI model. In the proposed models, the representative values of particle diameter, a friction velocity in tidal flow and a wave height were selected as the explaining variables by using a multivariate analysis. The calculated HSI described well the suitable condition for these crabs. These models were applied to the estimation of inhabitable areas in the Yoshino River and it was found that this assessment procedure was very effective to evaluate inhabitable potential for sand crab family.
\end{abstract}

\section{1. はじめに}

徳島県の吉野川河口では東環状大橋（仮称）が現在建 設中であり，希少種であるシオマネキ等をはじめ数多く のベントスへの影響が懸念されている。

ベントスの生息環境は, 潮汐や波浪によって日々変化 する底質の粒度組成の影響を強く受け，干出時に干潟表 層の砂泥から有機物を摂食する食性を持つスナガニ科の 生息は，底質の粒度組成が密接に関係している。

藤田ら（2006）は粒度組成の代表量と潮汐で発生する 底面摩擦速度をパラメータとするシオマネキの生息環境 評価モデルを提案したが, 将来予测をする上で表層底質 の粒度組成の推定方法が課題となった。 そして藤田ら （2007）は波浪統計データに基づいて平衡状態における 表層底質の粒度の評価方法を提案した。

本研究では, 吉野川の河口干潟で2003年から2007年ま での間に採取した底質試料のデータと，2006年の6月に 行われた, 東環状大橋建設におけるモニタリング調査の 結果をあとに, スナガニ科（シオマネキ, 八クセンシオ マネキ, ヤマトオサガニ, チゴガニの計4種）の生息環 境評価モデルを HSI（Habitat Suitability Index）モデルを 用いて提案した。ささらに2007年度に提案した, 平衡状態 における表層底質の粒度分布の推定方法を適用して, 吉 野川の河口全体の生息環境評価を実施した。

\section{2. スナガニ科の生息環境評価モデルの作成}

(1) スナガニ科の HSI モデル
吉野川河口には, 準絶滅危惧種（環境省カテゴリー） であるシオマネキ属の生息が多数確認できる. そこでシ オマネキの生息が顕著な場所における，過去 5 年分の粒 度分布と, その平均值のグラフを図-1に示した。吉野川 に生息しているシオマネキ生息場の粒度組成は20～30 $\mu \mathrm{m}$ 程度のシルトと $100 \mu \mathrm{m}$ 以上の細砂にピークを持つ ような2峰性を示すことが多い. また他のスナガニにつ いてあ同様に粒度分布を平均化し, 図-2に示している.

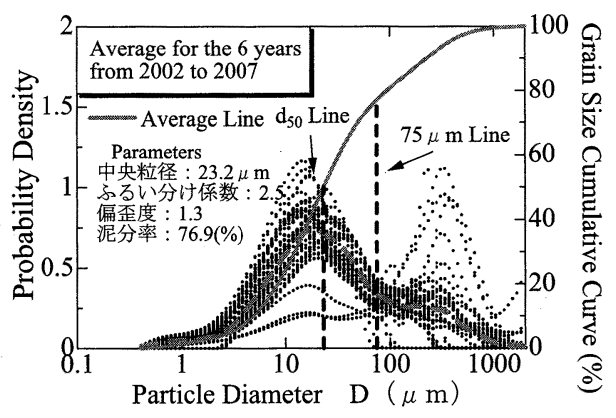

図-1 シオマネキ生息場の平均粒度分布 （・：シオマネキ生息場の粒度の実測値）

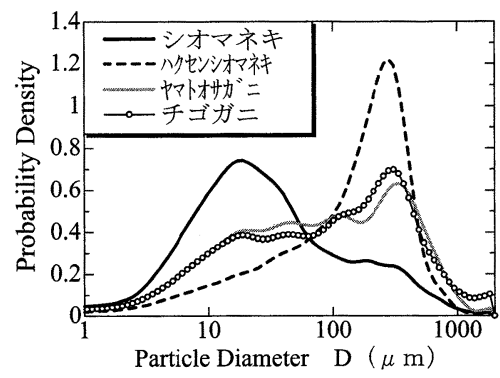

図-2 スナガニ科生息場の粒度組成の平均粒度分布 
なおヤマトオサガニとチゴガニについては徳島県 （2008）の調查デー夕を用いた。粒度組成はスナガニに とって摂餌および造巣の特性に密接に関係していると言 われており (小野, 1995), この結果から対象としたス ナガニ科の生息する可能性の高い粒度組成が分かる。

表-1にスナガニ科の動物の生息と関係の深い指標を整 理した. HSI モデルに用いる指標は, 生物の生活史に関 係のある量を抽出することが重要であるが，環境影響評 価に用いるためには, 調査の容易さ, 工学的に予測可能 であることむ重要な要素である。そこで HSI モデルを 構築するために表-1の*印を重要因子として採用した。 具体的には2003年〜2006年にかけて採取した底質の粒度 分布デー夕に加え, 徳島県が実施している環境調査の結 果と, 宇野ら（2003a）が提案している潮汐流によって 発生する底面摩擦速度の最大值を用いて対象種の HSI モデルを作成した．モデルの作成方法は宇野ら（2003b） が提案している多変量解析を導入することで因子間に重 みつけを行う方法を採用した。

波浪による擾乱の評価については高山ら（1991）と間 瀬ら（1999）によって報告された波の回折効果を導入し た多方向不規則波の波浪变形計算法を用いて波高を解析
した。計算条件は吉野川河口の小松島波浪観測所で観測 された 3 年間のデー夕を元に, 沖波の波高, 周期, 波向 きの頻度が最む高い条件 $\left(\mathrm{H}_{1 / 3}: 0.38 \mathrm{~m}, \mathrm{~T}_{1 / 3}: 2.5 \mathrm{~s}\right.$, 波向 き：南東）で，潮位は H.W.L（T.P：+0.76m）である.

図-3に波浪解析の計算領域を, 図-4にその結果となる波 高分布図を示し，生息場の波高を擾乱作用の因子とした。 カニ類の SI（Suitability Index）モデルを作成するにあ たり, シオマネキと八クセンシオマネキは複数年のデー

表-1 スナガニ科の行動生態に関係する指標

\begin{tabular}{|c|c|c|}
\hline 行動生態 & 指標 & 調査の容易さ \\
\hline \multirow{2}{*}{ 摂餌 } & 粒度組成 ${ }^{*}$ & 0 \\
\hline & クロロフィル量 強熱減量 & $\triangle$ \\
\hline 摂䬣効率 & 地盤高度 ${ }^{*}$ & 0 \\
\hline 造巣 & 粒度組成 ${ }^{*}$ 貫入抵抗値 & $\mathrm{O}$ \\
\hline 底質の安定性 & 植生 地盤高度 ${ }^{*}$ 潮汐 $^{*}$ & 0 \\
\hline 活動時間 & 地盤高度 ${ }^{*}$ 気温 水温 & 0 \\
\hline 滞留効果 & 河口閉塞度 & $\triangle$ \\
\hline 微細粒子の堆積 & 河川の流れ 潮流 ${ }^{*}$ & $x$ \\
\hline 砂質土の堆積 & 波浪による擾乱" & $\triangle$ \\
\hline
\end{tabular}

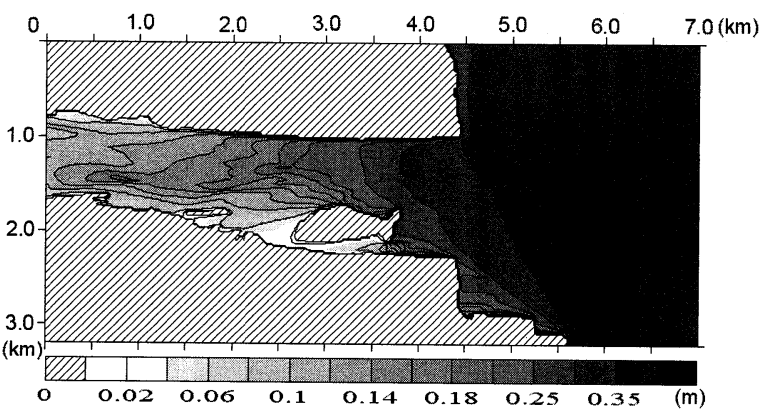

図-4 波高分布図 $\left(H_{1 / 3}: 0.38 \mathrm{~m}, \mathrm{~T}_{1 / 3}: 2.5 \mathrm{~s}\right.$, H.W.L $)$

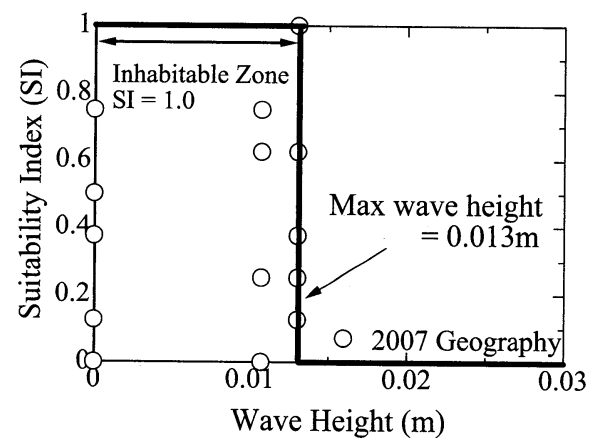

図-6 波高のSI モデル（シオマネキ）
図-5 中央粒径のSI モデル（シオマネキ）

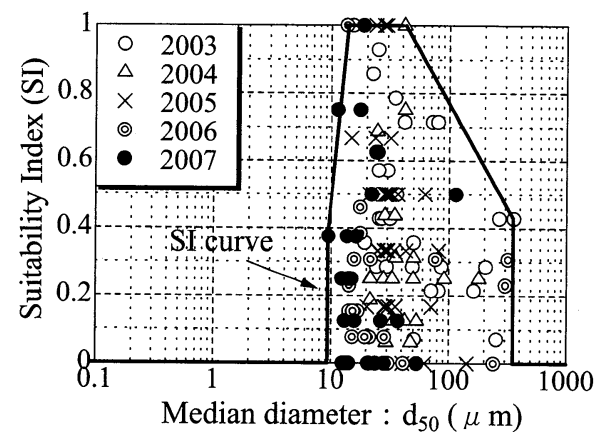

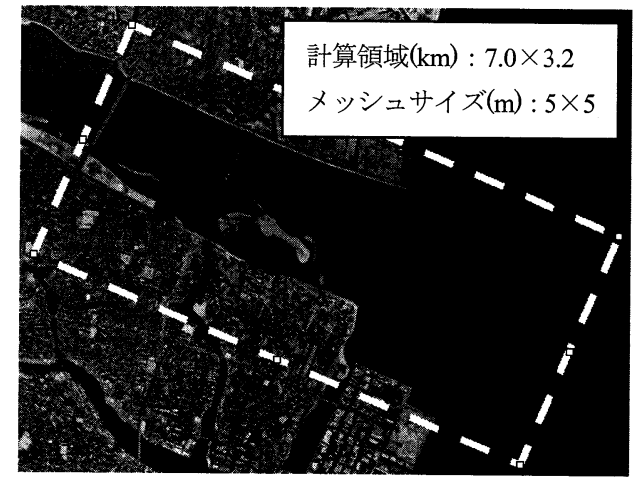

図-3 計算領域（吉野川河口部） 
夕を用いているので, 各年度に確認された最大活動個体 数を $\mathrm{SI}=1.0$ としている. なお季節変動によって大きく 変化する小型個体は含めない，これらのデータから SI モデルを作成し, 多変量解析によって重要な因子を抽出 した. SI モデルの例として, 図-5と図-6にシオマネキ の中央粒径と波高のSI モデルを示す. 次に抽出した SI モデルを用いて粒度組成の代表量と底面摩擦速度の SI モデルから目的変数を SI, 説明変数を採用した因子で 多变量解析の全数法を行うことで重み付けを行った. 重 み付けをした結果に加え, 平常時に波高が高い場ではス ナガニ科は生息できないとしてモデルを作成した。 それ ぞれのカニの HSI モデルを式(1)〜(4)に示す.

$$
\begin{aligned}
& \underset{\text { 沂神 }}{H S I}=S I_{d 50}^{0.507} \times S I_{P 75}^{0.748} \times S I_{U_{*}}^{1.113} \times S I_{H} \\
& \underset{\text { 八と沂标 }}{H S I}=S I_{d 50}^{0.405} \times S I_{S_{0}}^{0.214} \times S I_{U_{*}}^{1.469} \times S I_{H} \\
& \underset{\text { 防材政 }}{H S I}=S I_{S_{k}}^{0.34} \times S I_{P 75}^{0.656} \times S I_{U_{*}}^{0.448} \times S I_{H} \\
& \underset{\text { チゴガ゙ }}{H S I}=S I_{d 50}^{0.407} \times S I_{S_{k}}^{0.675} \times S I_{P 75}^{0.421} \times S I_{H}
\end{aligned}
$$

変数について, $d_{50}$ : 中央粒径, $S_{k}$ : 偏歪度, $S_{0}$ ：ふる い分け係数, $P 75$ : 泥分率, $U_{*}$ : 冠水時最大底面摩擦速 度, $H$ : 波高を表している. 重み付けによって従来の HSI モデルでは考慮できていない, 対象種にとって重要 な因子を特定することができる。図-7と図-8にシオマネ キとチゴガニの HSI モデルの結果を例として示し, 表-2 に作成したモデルの重相関係数と最小 HSI(以下 M.H と する.）を示している.この結果から，スナガニ科が生 息するために確保するべき必要最低限な HSI が分かる.

\section{(2) スナガニ科評価モデルの活動個体数確認率}

作成したスナガニ科の HSI モデルの精度を活動個体 数確認率: $\mathrm{P}_{\mathrm{a}}(\mathrm{x})$ で求めた. HSI モデルを構築するために 用いたデータ以外に, 対象種が全く生息していない場の デー夕等を含めて算出しており, (1)M.H 以下で活動個 体数がある場合，(2)M.H 以上で活動個体数が0個となる 場合をはずれ：(9)，(3)HSI が M.H 以上の時に活動個体 数がある, (4)M.H 以下で活動個体数が0個の場合を的中 : ○とした. 図-9〜図-12 は対象種の活動個体数確認率を 示している。これらの図からはコドラート内で少なくと あ1匹以上の活動を確認するためには, M.H を確保する ことでシオマネキは約 $79.9 \%$ ，八クセンシオマネキは約 $60.2 \%$, ヤマトオサガニは約 $53.3 \%$, チゴガニは約 $45.7 \%$ の $\mathrm{P}_{\mathrm{a}}(\mathrm{x})$ になることが示された。例としてチゴガニの $\mathrm{P}_{\mathrm{a}}(\mathrm{x})$ を $60 \%$ 以上で再現するためには, HSI を0.6以上確保 する必要があるということを示している. この結果, 作 成したモデルは HSI を高くすると $\mathrm{P}_{\mathrm{a}}(\mathrm{x})$ は高くなり，よ り多くの活動個体数が定着できる可能性が高くなること
を示した。

\section{3. 吉野川河口のスナガニ科の HSI マップ作成}

(1) 表層粒度分布シミュレーション

粒度によって生息が大きく左右される干潟のベントス は現在の場の状態を評価できたとしても, 将来予測する ことが困難とされている.

本研究では, 作成した HSI モデルに応用させるため, 藤田ら（2007）に提案している波浪統計データから表層 粒度分布を推測する方法を用いた。図-13に吉野川の河 口全体を解析した広域表層粒度分布から中央粒径の分布 図を示し，図-14にスナガニ科が多く生息している場の 近辺を拡大して表示している.この結果加ら, 波浪によっ て堆積する底質の特性を把握することができ, 作成した HSI モデルに応用することで広域の生息評価が可能にな る.

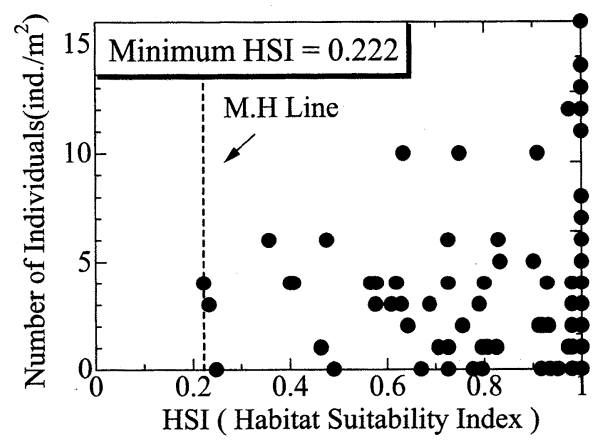

図-7 シオマネキのHSI モデル

\begin{tabular}{|c|c|c|c|c|}
\hline & 沂神 & ハクセンジ权神 & 㠶㔗゙ニ & チゴガニ \\
\hline 重相関係数 & 0.409 & 0.479 & 0.556 & 0.378 \\
\hline 最小 HSI & 0.222 & 0.248 & 0.055 & 0.316 \\
\hline
\end{tabular}

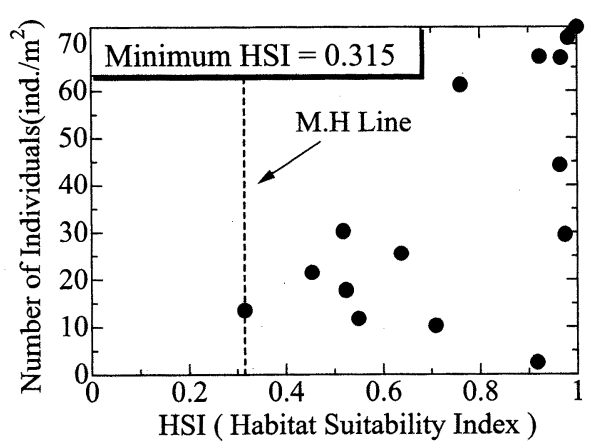

図-8 チゴガニのHSI モデル

表-2 カニ類の HSI モデルの相関と最小 HSI 


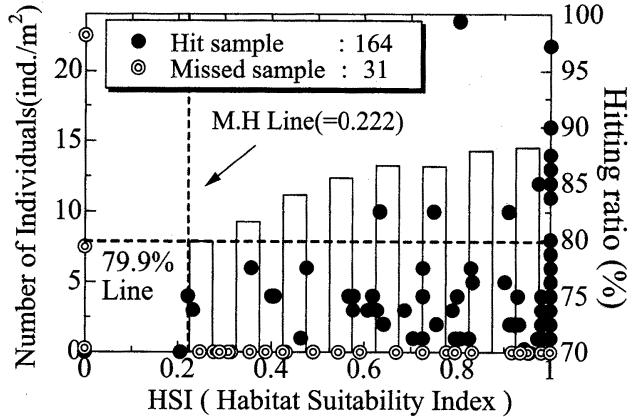

図-9 シオマネキの的中率

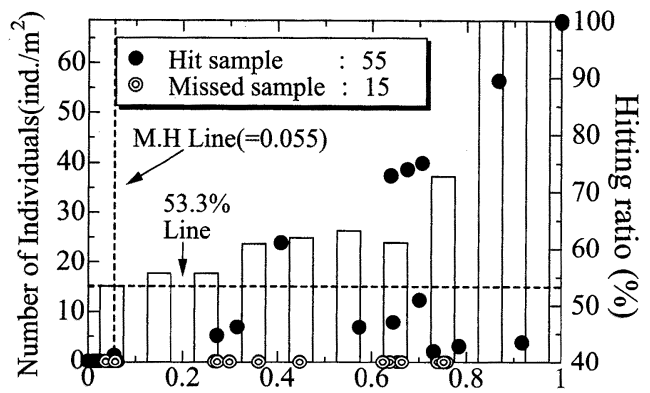

HSI ( Habitat Suitability Index )

図-11 ヤマトオサガニの的中率

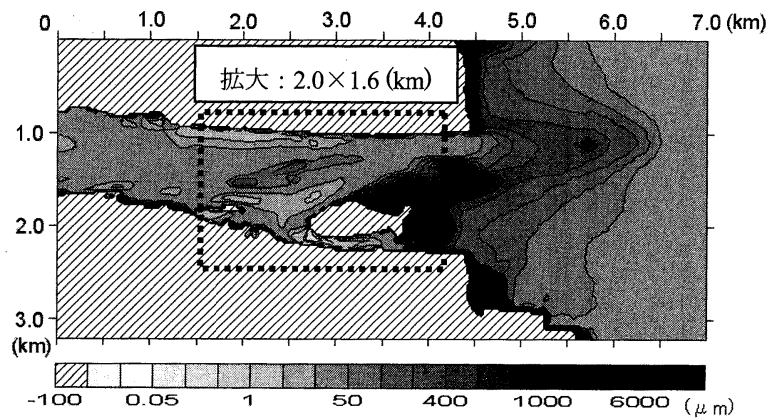

図-13 表層底質の中央粒径の分布図

\section{(2) スナガニ科の HSI マップ作成}

過去に数多く作成された HSI モデルは将来予測不可 能なパラメー夕を扱っていること，採用した因子間の相 関を考慮していないこと, 調査した一地点ごとの評価は 可能だが広域評価ができないことが問題点である。それ らの問題点を改善し, 吉野川の河口のように広範囲な場 において，スナガニ科の生息環境評価を検討した，図一 15〜図-18がその結果である. ○が M.H 以上の HSI があ る場所を示しており, 枠で囲まれた領域は徳島県が実施 したモニタリング調査で報告された対象種を目視で確認 できた範囲を示している。この結果から吉野川河口で HSI が示すポイントは, 概ね対象種が生息している場の

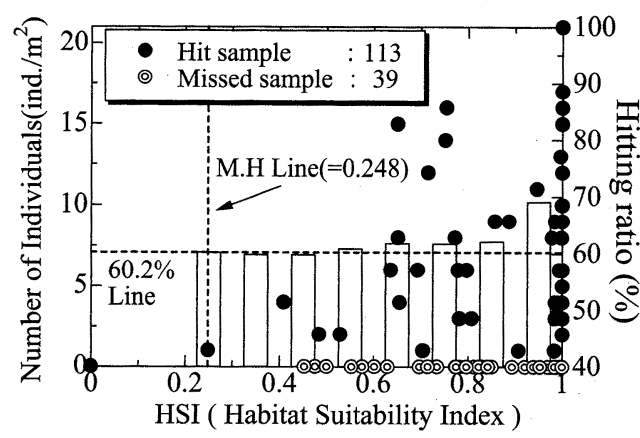

図-10 ハクセンシオマネキの的中率

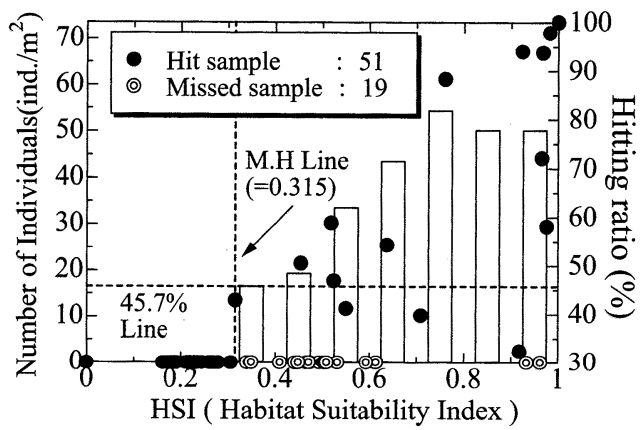

図-12 チゴガニの的中率

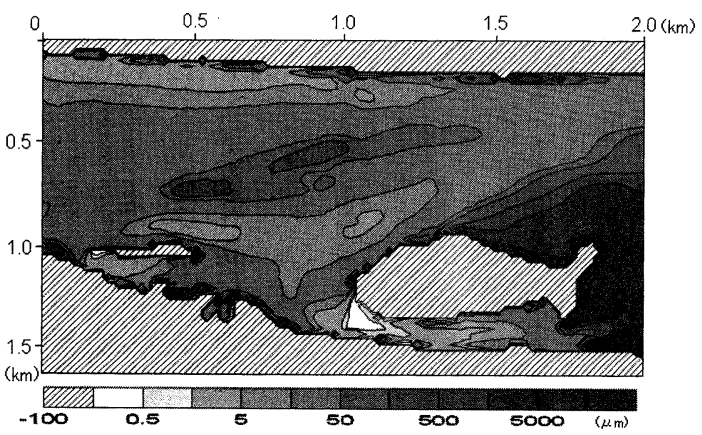

図-14 表層底質の中央粒径の分布図（拡大）

近辺を示しており，生息する可能性の高い適性箇所を選 定することができた。しかし適性外の場所にヒットする 箇所，生息しているにも関わらず，HSI が示さない点も 示された。これは H.W.L よりも高度が高い箇所に生息 しているスナガニ科について, 波浪計算の領域外となり 粒度組成を再現することができないこと, 複雑な地形の 回折効果で波高に誤差等が生じること，HSI モデルに採 用した因子だけでは不十分である点が精度を下げる原因 になると考えられる。今回の結果からは波浪の影響がな い場の粒度組成を潮位変動によって再現することが課題 となり，植生の有無や河川の流れによる影響を考慮する ことでより正確なモデルになると示唆される. 


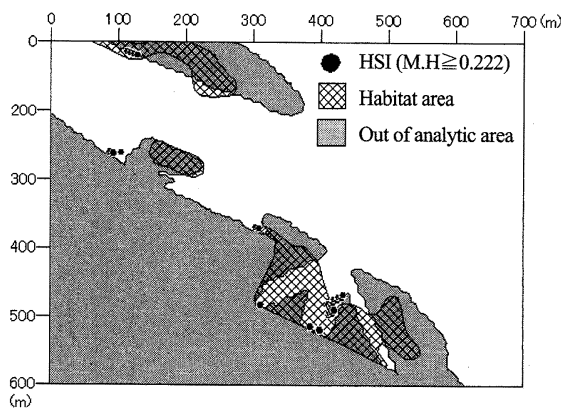

図-15 シオマネキのHSI マップ

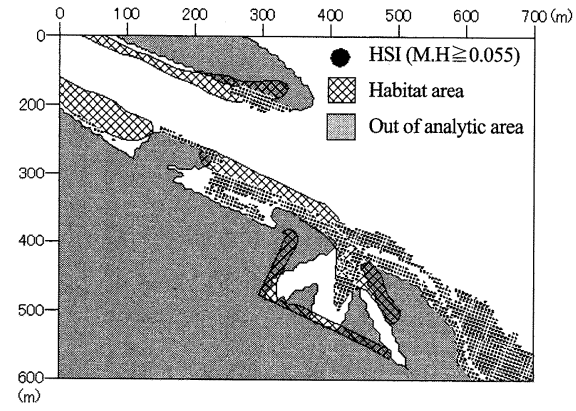

図-17 ヤマトオサガニのHSI マップ

\section{4. まとめ}

本研究は河口干潟に生息する砂泥を洯食するスナガニ 科に注目し，生息環境評価モデルの精度向上之広範囲の 環境影響評価を目指したあのである．将来予測が可能で ある物理的因子による HSI モデルを作成し，モデルの 因子間を統計的処理で考慮することによって，精度向上 を行った．作成した HSI モデルは粒度指標と潮汐によっ て生ずる底面摩擦速度, 波高のみで評価可能である。

大河川の河口砂州における粒度構成のシミュレートは 外海加らの波浪の頻度に注目，波浪の頻度によって表層 底質が平衡状態を形成すると考え，粒度分布を評価する 手法を提案, HSI モデルへ応用させた。 波浪の長期デー 夕を使用しているため，この手法では短期間の粒度変化 を表現するには適していない。

吉野川河口全体を評価した結果，広範囲の中からある 程度近い所の生息可能場の推定はできたが，目視で確認 できる生息範囲を詳細に再現することはできなかった。 波浪が卓越しない場の粒度組成を予測することが今後の 課題となり，モデルに採用する因子を増やすこと，計算 領域の改善, 浮遊土砂の細粒分の沈降, 河川の流れによ

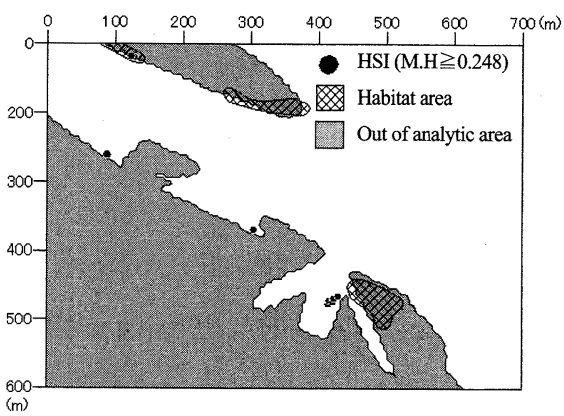

図-16 ハクセンシオマネキのHSI マップ

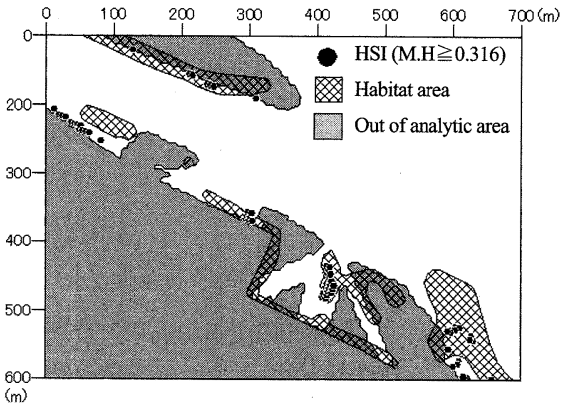

図-18 チゴガニのHSI 図マップ

る影響等を考慮することで生息可能場所をより精度良く 再現できる可能性が示唆された.

\section{参 考 文 献}

高山知司・池田直太・平石哲也 (1991)：砕波および反射を考慮 した波浪変形計算，港湾技術研究所報告，Vol.30，No.1， pp.21-67.

小野勇一 (1995)：干潟のカ二自然誌，平凡社，pp.59-117.

間瀬 肇・国富将嗣・高山知司 (1999)：三島豊秋:波の回折を考 慮した多方向不規則波の変形計算モデルに関する研究，土 木学会論文集, No.628，II-48，pp.177-187.

宇野宏司・中野 晋・古川忠司 (2003a) : 河口干潟扔よび砂州 の底質に及ぼす潮汐流の効果，河川技術論文集，Vol. 9, pp.281-286.

宇野宏司・中野 晋・古川忠司 (2003b)：重み付き評価指標を 用いたシオマネキ生息地適性評価, 水工学論文集, 第47巻, pp.1075-1080.

藤田真人・寺澤尚晃・中野 晋 (2006)：四国全域におけるシオ マネキの生息環境評価，海岸工学論文集，第53巻，pp.1126 -1130 .

藤田真人・中野 晋・安芸浩資・安井勝志 (2007)：河口干潟の 平衡粒度分布の推定と底生動物の生息環境評価，海岸工学 論文集，第54巻，pp.1171-1175.

徳島県（2008）：東環状大橋（仮称）環境モニタリング調査平成 18 年度年報. 